\title{
Perancangan Jaringan NB-IoT Menggunakan Standalone Frekuensi 900 MHz Di DKI Jakarta
}

\section{The Design NB-IoT Network by Standalone Frequency of $900 \mathrm{MHz}$ in DKI Jakarta}

\author{
Melinda Br Ginting ${ }^{1}{ }^{*}$, Alfin Hikmaturokhman ${ }^{2}$, Muntaqo Alfin Amanaf ${ }^{3}$ \\ 1,2Program Studi S1 Teknik Telekomunikasi, ${ }^{3}$ Program Studi D3 Teknik Telekomunikasi, \\ Fakultas Teknik Telekomunikasi dan Elektro, Institut Teknologi Telkom Purwokerto \\ JL. DI Panjaitan No.128 Purwokerto, 53147, Jawa Tengah, Indonesia \\ 1,*Penulis korespondensi: 7101227@ittelkom-pwt.ac.id \\ 2alfin@ittelkom-pwt.ac.id, ${ }^{3}$ muntaqo@ittelkom-pwt.ac.id
}

Received on 05-07-2019, accepted 01-08-2019, published 01-08-2019

Abstract

Teknologi telekomunikasi celluler semakin berkembang dengan sangat pesat. Hal ini dapat dilihat dari semakin banyaknya jumlah user yang semakin bertambah dan menuntut operator untuk memberikan layanan akses secara maksimal dengan cakupan yang luas tidak hanya untuk mobile phone tetapi juga device. Berdasarkan kebutuhan tersebut hadirlah teknologi telekomunikasi terbaru dengan mendukung device Internet of Things yaitu Narrowband Internet of Things (NB-loT). Pada tahun 2016 3GPP standarisasi untuk NB-loT, teknologi yang mampu memberikan layanan device loT, dengan cakupan yang luas, low data rate $50 \mathrm{kpbs}$, dan penggunaan daya $43 \mathrm{~dB}$ untuk Standalone. Pada penelitian ini frekuensi yang digunakan adalah frekeunsi $900 \mathrm{MHz}$ dengan skema Standalone yang menggunakan bandwidth $200 \mathrm{kHz}$. Parameter yang dianalisis pada skripsi ini ialah performansi kapasitas terhadap user connected berdasarkan simulasi diperoleh jumlah user yang terhubung sebesar pada skema Standalone sebesar 109.933 device user. Throughput yang dihasilkan ialah 85 Mbps untuk skema Standalone. Performansi coverage yang dianalisa ialah nilai SINR yang diperoleh pada skema Standalone 4,73 dB. Nilai RSRP yang diperoleh dari simulasi ialah sebesar - 68,53 dBm untuk Standalone. Serta, nilai BLER yang dihasilkan untuk skema Standalone yaitu 0,03

Keywords: NB-IoT, Performance parameters, Skema standalone.

\section{Abstract}

Cellular telecommunications technology is snowballing. This phenomenon can be seen from the increasing number of users who demand operators to provide maximum access services with broad coverage for mobile phones and devices. Based on these needs, the latest telecommunication technology is presented by supporting the Internet of Things devices, namely the Narrowband Internet of Things (NB-IoT). In 2016 3GPP standardized for NB-loT, a technology capable of providing loT device services, with broad coverage, a low data rate

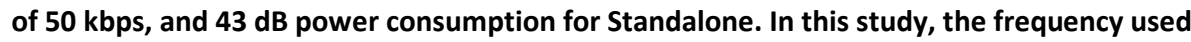
is $\mathbf{9 0 0} \mathbf{~ M H z}$ with a Standalone scheme that uses a bandwidth of $200 \mathrm{kHz}$. The parameter analyzed in this thesis is the capacity performance of connected users. Based on the 


\begin{abstract}
simulation, the number of connected users is 109,933 device users. The resulting throughput is $85 \mathrm{Mbps}$ for the Standalone scheme. The analysis of the coverage performance is the SINR value obtained in the Standalone scheme of $4.73 \mathrm{~dB}$. The RSRP value obtained from the simulation is $\mathbf{6} 6.53 \mathrm{dBm}$ for Standalone. Also, the BLER value generated for the Standalone scheme is $\mathbf{0 . 0 3}$.
\end{abstract}

Keywords: NB-IoT, Parameter performansi, Standalone scheme.

\title{
I. Pendahuluan
}

Dalam perkembangannya telekomunikasi sangatlah pesat, Hal ini dapat dilihat dari munculnya berbagai teknologi terbaru yang mendukung kinerja dari telekomunikasi salah satu teknologinya ialah Internet of Things (IoT). Diperkirakan pada tahun 2020 komunikasi tidak hanya dibutukan oleh manusia akan tetapi oleh perangkat, dengan semua bentuk komunikasi serta interaksi dapat terhubung, dengan memanfaatkan penggunaan pita kecil (narrowband) dalam bentuk pengiriman datanya. [1] Narrowband IoT (NB-IoT) merupakan salah stau teknologi komunikasi IoT device yang menggunakan pita kecil, dengan latensi 10 detik, menyediakan lebih dari 50000 device untuk setiap cell atau setara dengan 40 device dalam satu rumah. Serta, baterai yang tahan lama hingga 10 tahun. NB-IoT merupakan teknologi telekomunikasi yang memanfaatkan penggunaan frekuensi $900 \mathrm{MHz}$ pada GSM ataupun LTE dengan bandwidth LTE $10 \mathrm{MHz}$ dan menggunakan $200 \mathrm{kHz}$ dari total bandwidth GSM yang dimiliki oleh teknologi telekomunikasi yang sudah ada.[2] Untuk penerapan NB-IoT sendiri memiliki beberapa skema model NB-IoT yang dapat digunakan diantaranya ialah Standalone dengan mengalokasikan bandwidth NB-IoT pada keseluruhan kanal sebesar $200 \mathrm{kHz}$. Bentuk layanan dari IoT device sendiri pada teknologi NB-IoT salah satunya ialah machine technology communication (MTC). [3] Dengan semakin berkembangnya penggunakan teknologi telekomunikasi yang berbasis pada IoT device yang bisa diterapkan, salah satunya ialah menerapkannya di kota - kota yang berkembang, industrial dan kota dengan konsep smart city. Untuk uji performansi penerapan NB-IoT sendiri masih belum ada. Oleh karena itu, pada penelitian skripsi ini, penulis ingin melakukan penelitian uji performansi dari jaringan NB-IoT yang diterapkan di DKI Jakarta. Dengan melihat bentuk performansinya berupa nilai SINR, BLER dan RSRP dari sisi performansi coverage yang diperoleh dan untuk sisi performansi kapasitas akan dianalisis dari nilai throughput dan user connected yang diperoleh dari skema Standalone.. Berdasarkan latar belakang tersebut maka, penulis mengambil topik skripsi yang berjudul "Perancangan Jaringan NB-IoT Menggunakan Standalone Pada Frekuensi 900 MHz Di DKI Jakarta" dengan memanfaatkan data existing yang sudah ada.

\section{Metode Penelitian}

Pada penelitian ini, akan dilakukan perancangan jaringan untuk NB-IoT pada frekuensi $900 \mathrm{MHz}$ di Kota DKI Jakarta dengan menggunakan site existing. Untuk melakukan suatu perancangan jaringan dan melakukan simulasi perancangan jaringan tersebut, dibutuhkan suatu perhitungan untuk mengetahui jumlah estimasi site yang dibutuhkan pada area DKI Jakarta. Kemudian, simulasi perancangan jaringan dilakukan dengan menggunakan site existing apabila jumlah site estimasi lebih sedikit dibandingkan jumlah site existing yang sudah ada. Simulasi perancangan dilakukan dengan menggunakan software atoll 3.3.2 dengan menggunakan skema NB-IoT yaitu Skema Standalone. Pada perancangan tersebut dibedakan berdasarkan power dan bandwidth yang digunakan yaitu Standalone dengan power $43 \mathrm{dBm}$ dan bandwidth $200 \mathrm{kHz}$.

Setelah melakukan perancangan maka akan dilakukan simulasi performansi berdasarkan kapasitas dan coverage terhadap skema Standalone. Pada parameter performansi akan dilakukan suatu analisa terhadap nilai user connected dan Troughput untuk performansi kapasitas serta nilai RSRP, SINR dan BLER untuk performansi coverage yang akan dilakukan pada skema NB-IoT yaitu skema Standalone. 


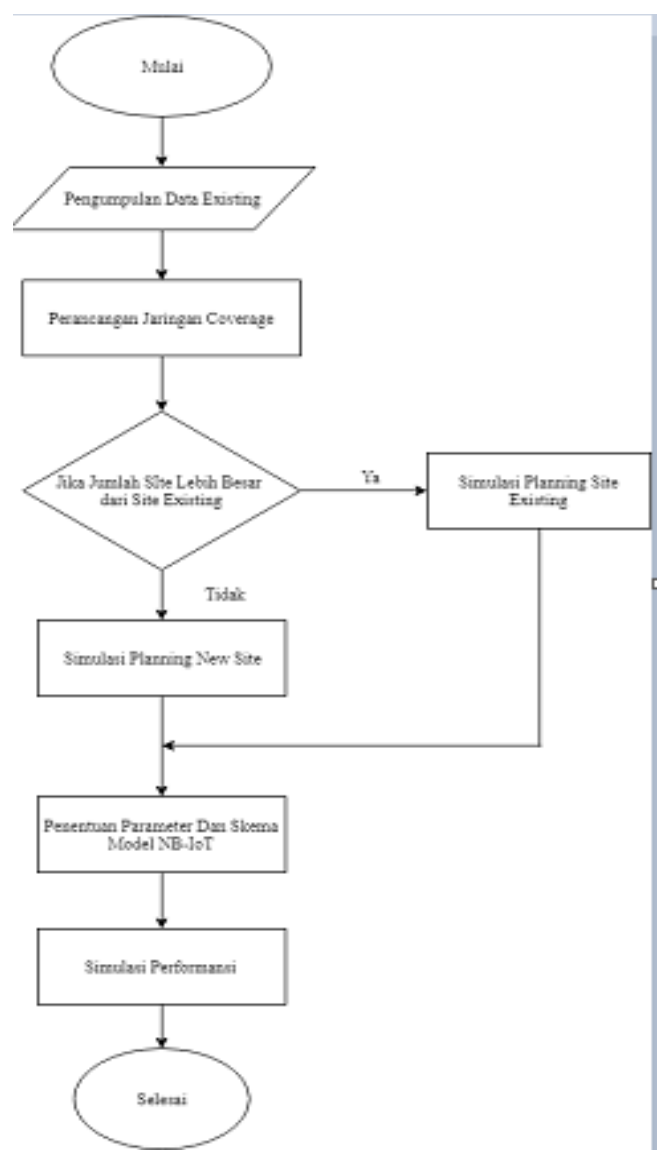

Gambar 1. Diagram Alur Penelitian

Gambar 1 merupakan gambar diagram alur dari penelitian, pada gambar tersebut menjelasakan mengenai proses yang dilakukan dari penelitian. Dimulai dari pengumpulan data existing, lalu melakukan kalkulasi estimasi site, penetuan parameter dan skema NB-IoT yang digunakan hingga melakukan simulasi dengan keluaran parameter yang akan dianalisis pada penelitian.

\section{A. Perancangan Coverage}

Perancangan jaringan NB-IoT yang dilakukan ialah secara coverage pada frekuensi $900 \mathrm{MHz}$ di DKI Jakarta. Perancangan jaringan ini dilakukan berdasarkan data site existing yang ada pada wilayah atau area tersebut. Akan tetapi, akan dilakukan perhitungan jumlah estimasi site terlebih dahulu untuk melihat, apakah hasil dari perhitungan tersebut memiliki jumlah site lebih banyak dari site existing atau lebih sedikit, jika lebih sedikit, maka akan menggunakan site existing, tetapi jika lebih banyak maka akan menggunakan site hasil perhitungan. Hal ini dibutuhkan sebagai bentuk perbandingan jumlah site yang akan digunakan. Apabila jumlah site dari perhitungan lebih banyak, maka akan Lalu hasil perhitungan perancangan jaringan tersebut akan dijadikan parameter pada simulasi berdasarkan coverage serta menggunakan parameter berdasarkan skema NB-IoT yaitu skema Standalone.

$L_{\text {urban }}=69,55+26,16 \log \log f c-13,82 \log h_{t e}-a\left(h_{r e}\right)+\left(44,9-6,55 \log h_{t e}\right) \log \log d(1)$

Dimana :

fc : frekuensi dari $150 \mathrm{MHz}$ sampai $1500 \mathrm{MHz}$

hte : tinggi efektif dari $e N o d e B$ dengan kisaran $30 \mathrm{~m}$ sampai $200 \mathrm{~m}$

hre : tinggi efektif antenna UE dari $1 \mathrm{~m}$ hingga $10 \mathrm{~m}$

d : jarak antara $e N o d e B$ dengan $\mathrm{UE}(\mathrm{km})$

a (hre) : merupakan faktor koreksi untuk tinggi efektif antena UE. 
Nilai faktor koreksi pada UE dibedakan berdasarkan wilayah perkotaan dengan luas wilayah kecil dan menengah ialah sebagai berikut :

$a_{(h r e)}=(1,1 \log f c-0,7) h_{r e}-(1,56 \log f c)-0,8$

Sedangkan, untuk daerah perkotaan yang memiliki daerah yang cukup luas, perhitungan faktor koreksi akan dilakukan sebagai berikut [18]:

$a_{(\text {hre })}=8,29\left[\left(\log \log \left(1,54 h_{r e}\right)\right)\right]^{2}-1,1 ;$ untuk f $\leq 300 \mathrm{MHz}$

$a_{(\text {hre })}=3,2\left[\left(\log \log \left(11,75 h_{r e}\right)\right)\right]^{2}-4,79 ;$ untuk f $\geq 300 \mathrm{MHz}$

Perhitungan jumlah site dapat dilakukan dengan mengetahui luas cakupan cell terlebih dahulu. Berikut merupakan persamaan untuk mencari luas cell.[21]

$L_{\text {cell }}=2,6 \times d^{2}$

Dimana :

Lcell : luas cakupan cell

d : radius cell

Jumlah Cell $=\frac{L_{\text {Area }}}{L_{\text {cell }}}$

Dimana :

Larea : luas area perencanaan

Lcell : luas cakupan cell

Jumlah Site $=\frac{\text { JumlahCell }}{3}$

\section{B. Perhitungan Kapasitas}

Pada simulasi perancangan dari NB-IoT akan dirancang menggunakan dua skema model yang sesuai dengan parameter yang sudah ditentukan pada skema NB-IoT. Dimana, skema model tersebut yang akan ditambahkan pada teknologi jaringan LTE yang akan digunakan. Untuk skema model yang digunakan pada NB-IoT ialah sebagai berikut :

1. Persentase (\%) Penduduk

Persentase (\%) jumlah penduduk yang dimaksud adalah, persentase jumlah penduduk di DKI jakarta terhadap jumlah penduduk yang ada di Indonesia. Adapun perhitungan untuk mencari nilai persentase penduduk (\%) sebagai berikut [5].

Persentase $(\%)=\frac{\text { Jumlah Penduduk Jakarta }}{\text { Jumlah Penduduk Indonesia }} \times 100$

2. Estimasi IoT Device

Perhitungan estimasi IoT device dilakukan untuk mengetahui jumlah IoT device yang ada di suatu area. Adapun perhitungan estimasi IoT device sebagai berikut [5].

IoT Device = IoT Device Indoneisa $x$ Persentase Penduduk (\%)

3. Jumlah User/Density $\left(\mathrm{km}^{2}\right)$

Jumlah user/density yang dimaksud adalah jumlah user $/ \mathrm{km}^{2}$ yang ada pada area tersebut. Adapun perhitungan untuk mencari nilai jumlah user/density sebagai berikut [5].

Jumlah user $=\frac{\text { jumlah penduduk jakarta }}{\text { Luas jakarta }}$ 


\section{Jumlah IoT Device Per Users}

Jumlah device per user yang dimaksud adalah estimasi jumlah device IoT yang digunakan atau yang dimiliki setiap user. Adapun perhitungan untuk mencari nilai jumlah device per user dapat dilihat pada persamaan [5].

$$
\text { Jumlah IoT Device Per User }=\frac{\text { Jumlah IoT device Jakarta }}{\text { Jumlah Penduduk Jakarta }}
$$

\section{Subscriber Device}

Subscriber device adalah jumlah device berdasarkan luas cakupan area yang akan disimulasikan. Adapun perhitungan untuk memperoleh jumlah subscriber device dapat dilihat pada persamaan [5].

\section{Subsciber Device $=$ Jumlah User $x$ Jumlah device per user}

\section{Downlink Throughput}

Perhitungan downlink throughput ialah untuk mengetahui nilai throughput maksimal yang diperoleh pada suatu site. Berikut merupakan persamaan untuk menghitung nilai downlink throughput. [6]

Throughput Cell $=12$ subscriber $x 14$ OFDM symbols $x$ code bit $x$ code rate $x$ RB $x 2$ Slot

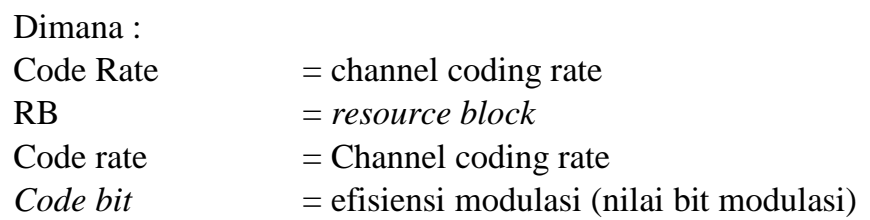

Throughput site = jumlah cell $x$ Throughput cell

Dimana :

Jumlah cell $\quad=396$ (cell existing)

Throughput cell = nilai throughput per cell

Pada penelitian ini, diperlukan untuk menentukan parameter yang akan digunakan berdasarkan standarisasi spesifikasi dari NB-IoT. Serta menentukan skema yang akan digunakan. Berikut merupakan tabel dari standarisasi spesifikasi dari NB-IoT.

Tabel 1 NB-IoT Spesifikasi

\begin{tabular}{|c|c|}
\hline Parameter & Value \\
\hline Frequency Band & $900 \mathrm{MHz}$ \\
\hline Bandwidth & $180 \mathrm{Khz}$ \\
\hline Porpagation condition & Urban \\
\hline Base Station antena & $\begin{array}{c}\text { In-Band (2 Tx antena dan 2 Rx antena), } \\
\text { Standalone (1 Tx antena dan 2 Rx Antena }\end{array}$ \\
\hline Base station power level & Standalone 43 dBm, In-Band 35 dBm \\
\hline
\end{tabular}

1. Skema Standalone

Standalone merupakan skema model dari performansi pada NB-IoT yang digunakan pada GSM akan tetapi dapat dialokasikan untuk teknologi LTE, dengan menggunakan frekuensi $900 \mathrm{MHz}$ dan bandwidth sebesar $200 \mathrm{KHz}$. Konsep Standalone ialah refarming spectrum pada GSM dan menggunakan $180 \mathrm{kHz}$ kanal bandwidth GSM dengan $10 \mathrm{kHz}$ sebagai guard antara teknologi yang dibunakan dengan NB-IoT. Akan tetapi, jika dialokasikan pada LTE guard tersebut akan berubah nilai menjadi $100 \mathrm{kHz}$ dengan total kapasitas yang dibutuhkan NB-IoT untuk skema Standalone adalah $400 \mathrm{kHz}$. 
Tabel 2 Standalone Parameter

\begin{tabular}{|c|c|}
\hline Operation Mode & Standalone \\
\hline Frekuensi (MHz) & 900 \\
\hline Tx Power NB-IoT $(\mathrm{dBm})$ & 43 \\
\hline Bandwidth $(\mathrm{kHz})$ & 200 \\
\hline Channel Bandwidth $(\mathrm{kHz})$ & 180 \\
\hline SINR $(\mathrm{dB})$ & -4.6 \\
\hline Receiver Sensivity & -121.0 \\
\hline Coupling Loss (MCL) (dB) & 164.0 \\
\hline
\end{tabular}

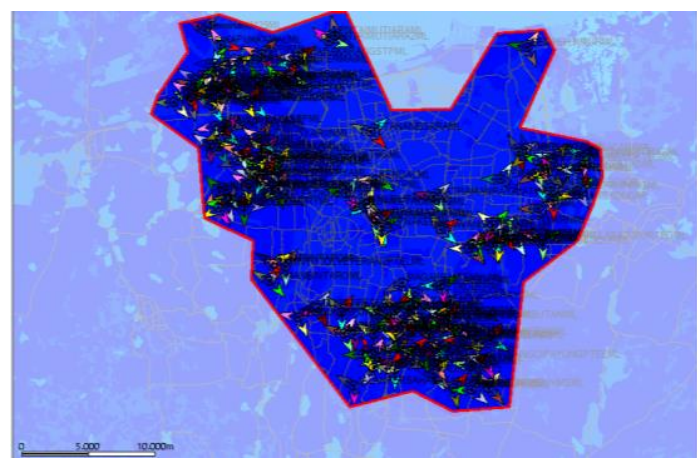

Gambar 2 Simulasi Skema Standalone

Pada penelitian ini dilakukan simulasi secara kapasitas dan coverage pada NB-IoT dengan menggunakan skema Standalone berdasarkan nilai parameter dari skema yang dapat dilihat pada tabel 2 dan tabel. Berikut merupakan parameter simulasi performansi kapasitas pada skema Standalone :

a. Simulasi Performansi kapasitas Berdasarkan Throughput

Parameter simulasi performansi dengan menganalisa nilai throughput Downlink yang digunakan dihasilkan untuk melayani device user oleh skema Standalone pada NB-IoT.

b. Simulasi Performansi Kapasitas Berdasarkan User Connected

Parameter simulasi performansi kapasitas berdasarkan user connected dilakukan pada kedua skema NBIoT yaitu skema Standalone untuk menganalisa jumlah device user yang terhubung pada jaringan NB-IoT.

Berikut merupakan parameter simulasi coverage pada NB-IoT yang dilakukan pada skema Standalone dilihat dari hasil prediction simulasi yaitu RSRP, SINR dan BLER, dengan berdasarkan data site existing yang berjumlah 132 site dan transmitter existing 365 transmitter untuk area DKI Jakarta dari simulasi NB-IoT. Pada simulasi coverage dengan skema Standalone menggunakan frekuensi $900 \mathrm{MHz}$ dengan bandwidth $10 \mathrm{MHz}$ dan $200 \mathrm{kHz}$.

\section{Reference Signal Received Power (RSRP)}

Reference signal received power merupakan power sinyal yang diterima eNodeB menuju ke UE. Pada penelitian ini akan menganalisa simulasi performansi dari parameter RSRP terhadap skema Standalone.

Tabel 3 Nilai RSRP [7]

\begin{tabular}{|c|c|}
\hline Keterangan & Nilai \\
\hline Very Good & $\leq-80 \mathrm{dBm}$ \\
\hline Good & $\leq-95 \mathrm{dBm}$ \\
\hline Bad & $\leq-110 \mathrm{dBm}$ \\
\hline
\end{tabular}




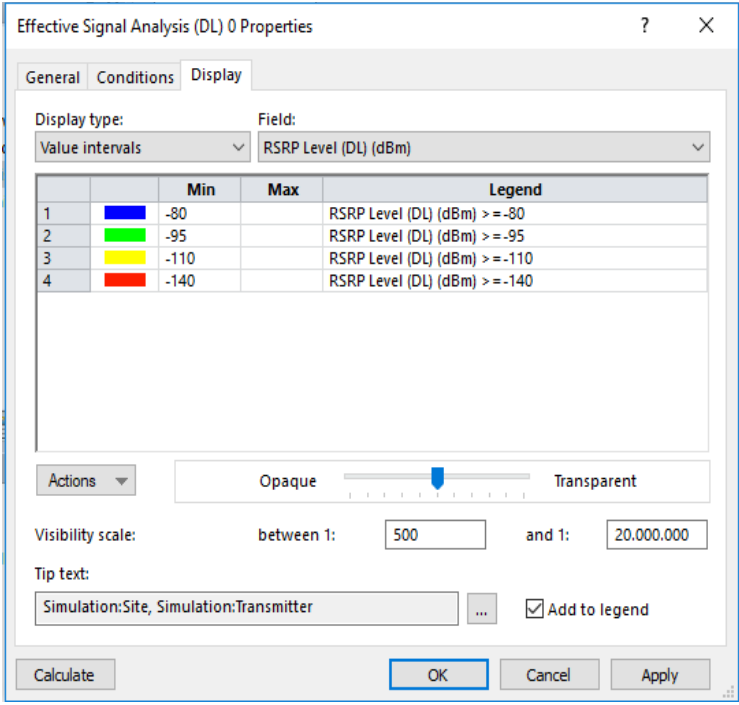

Gambar 3 RSRP

2. Sinyal Interference to Noise Ratio (SINR)

SINR adalah perbandingan kuat sinyal dengan noise interference dari resource yang lain. Parameter ini menunjukkan level daya minimum dimana user masih bisa melakukan layanan yang akan dianalisis pada skema Standalone.

Tabel 4 Nilai SINR[8]

\begin{tabular}{|c|c|}
\hline Keterangan & Nilai \\
\hline Good & SINR $\geq-1 \mathrm{~dB}$ \\
\hline Bad & SINR $\leq-1 \mathrm{~dB}$ \\
\hline
\end{tabular}

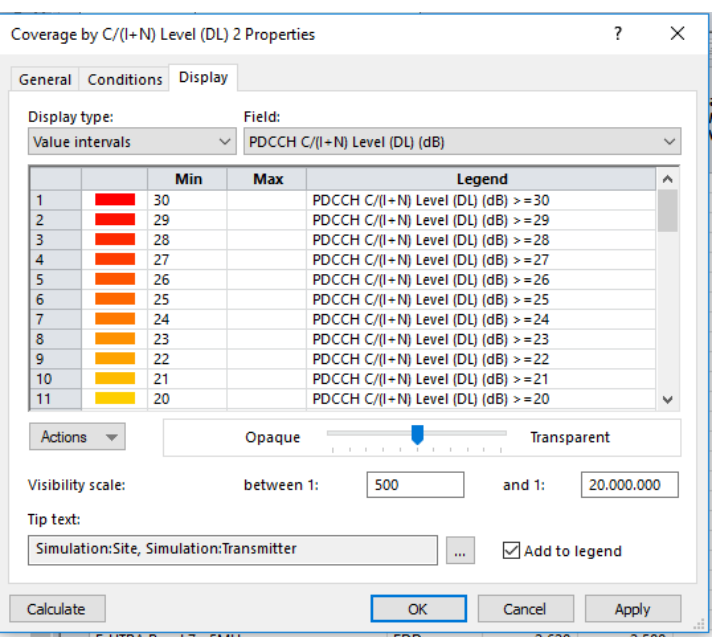

Gambar 4 SINR

\section{Block Eror Rate (BLER)}

Block eror rate merupakan salah satu analisis parameter performansi coverage dengan melihat nilai eror rate yang diperoleh dari data yang di transmisikan. 


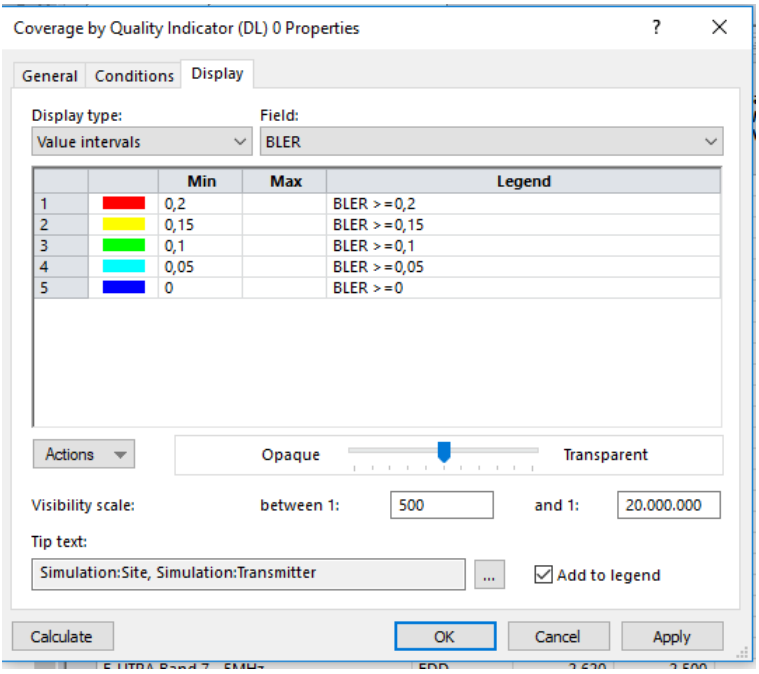

Gambar 5 BLER

\section{Hasil Pembahasan}

\section{Analisis Performansi Kapasitas Skema Standalone Terhadap User Connected}

Hasil dari simulasi performansi kapasitas skema Standalone terhadap parameter user connected dengan input subscriber device sebesar 31.785 dan jumlah device user yang mencoba terhubung sebesar mencoba terhubung sebesar 223.312 .

Tabel 5 User Connected Skema In-Band dan Standalone

\begin{tabular}{|c|c|c|}
\hline Skema Model & User Connected & Persentase (\%) \\
\hline Skema Standalone & 107.933 & 48,3 \\
\hline
\end{tabular}

Tabel 5 merupakan tabel user connected yang diperoleh dari skema In-Band dan Standalone. Pada tabel tersebut menjelaskan bahwa dari kedua skema memperoleh jumlah user connected yang berhasil terhubung sebesar 197.226 device user atau sebesar 88,5\% untuk skema In-Band. Sedangkan, untuk hasil dari simulasi performansi kapasitas pada skema Standalone menghasilkan jumlah user connected sebesar 107.933 atau sama dengan 48,3\% dari jumlah total device user yang mengcoba terhubung pada skema Standalone.

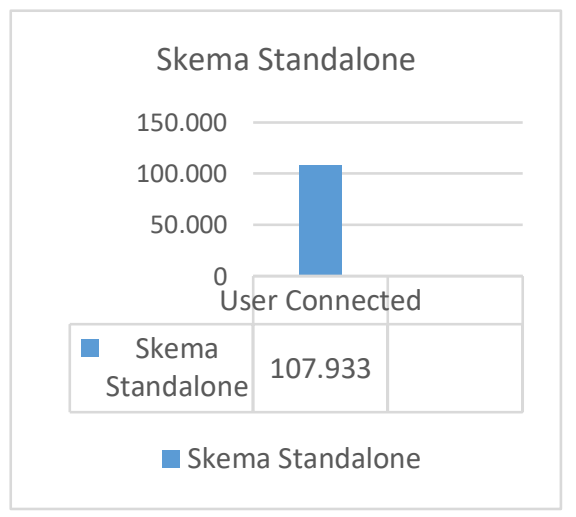

Gambar 6 Grafik User Connected Pada Skema Standalone 
Gambar 6 merupakan grafik dari user connected terhadap skema Standalone. Berdasarkan dari hasil yang peroleh berdasarkan simulasi kapasitas terhadap parameter user connected pada standalone memperoleh jumlah device user sebesar device user $48,3 \%$ dari total device user. Dari hasil simulasi jumlah user yang terhubung lebih jika melihat jumlah user yang mencoba terubung. Hal ini dikarenakan, bandwidth yang digunakan kecil yaitu sebesar $200 \mathrm{Khz}$.

\section{Analisis Performansi Kapasitas Skema Standalone Terhadap Throughput}

Untuk analisa performansi berdasarkan kapasitas pada skema Standalone terhadap nilai throughput yang diperoleh yaitu masih dengan input jumlah subscriber yang sama sebesar 31.758 subscriber device memperoleh throughput yang dapat dilihat pada tabel 4.5. Hasil nilai throughput yang diperoleh berdasarkan jumlah user device yang terhubung, dengan asumsi bahwa nilai throughput tersebut adalah throughput yang dibutuhkan atau yang digunakan oleh device user yang ada.

Tabel 6 Simulasi Throughput Skema Standalone

\begin{tabular}{|c|c|}
\hline Skema Model & Throughput (Mbps) \\
\hline Standalone & 85 \\
\hline
\end{tabular}

Tabel 7 merupakan tabel nilai throughput yang diperoleh berdasarkan hasil dari simulasi kapasitas terhadap throughput pada skema Standalone throughput yang diperoleh ialah sebesar $85 \mathrm{Mbps}$.

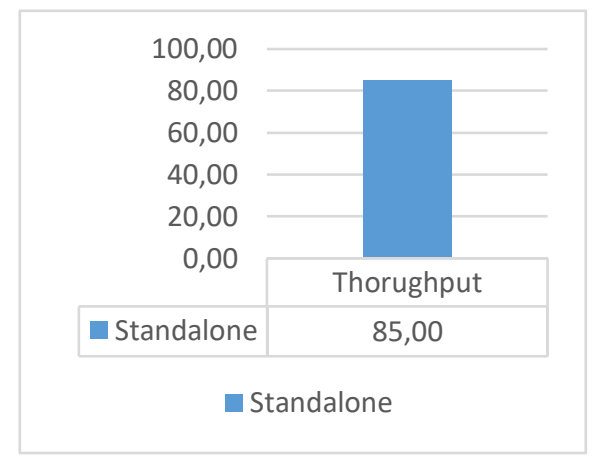

Gambar 7 Grafik Simulasi Throughput Skema Standalone

Gambar 7 merupakan grafik dari nilai dari simulasi throughput yang diperoleh pada skema Standalone berdasarkan performansi kapasitas. Setiap sitenya memiliki throughput sebesar 85 Mbps. Berdasarkan hasil dari simulasi throughput yang diperoleh pada skema standalone ntuk nilai throughput yang diperoleh ialah diperoleh nilai sebesar 85 Mbps merupakan nilai throughput dengan setiap site memiliki nilai throughput sebesar 0,64 Mbps.

Tabel 7 Hasil Perhitungan dan Simulasi Throughput Skema Standalone

\begin{tabular}{|c|c|}
\hline Parameter & Standalone \\
\hline Perhitungan Throughput (Mbps) & $87.816,96$ \\
\hline Simulasi Throughput (Mbps) & 85 \\
\hline
\end{tabular}

Tabel 7 merupakan tabel untuk hasil perhitungan nilai throughput yang telah diperoleh, dengan hasil simulasi yang dilakukan pada skema standalone yang diperoleh dari hasil perhitungan untuk mengetahui nilai maksimal dari throughput yang diperoleh bersadarkan kalkulasi yang akan dijadikan sebagai acuan untk nilai throughput pada simulasi.

\section{Simulasi Performansi Coverage Skema Standalone}

Simulasi performansi coverage pada skema Standalone dengan menggunakan frekuensi $900 \mathrm{MHz}$. Pada simulasi performansi coverage memiliki beberapa parameter simulasi coverage yang penting ialah spesifikasi parameter dari kedua skema yang berbeda yaitu dalam penggunaan power untuk base station NB-IoT. Pada skema Standalone menggunakan power sebesar $43 \mathrm{dBm}$. Serta, beberapa parameter lainnya 
yang digunakan dapat dilihat pada table 4.1. Untuk parameter performansi yang akan dianalisis adalah nilai dari RSRP, SINR dan BLER hasil dari simulasi NB-IoT pada skema Standalone.

\section{Analisis Performansi Coverage Skema Standalone Terhadap RSRP}

Simulasi performansi coverage pada skema Standalone dengan melakukan analisa terhadap parameter simulasi yaitu RSRP, yang merupakan niai daya sinyal yang diterima oleh device user pada skema Standalone.

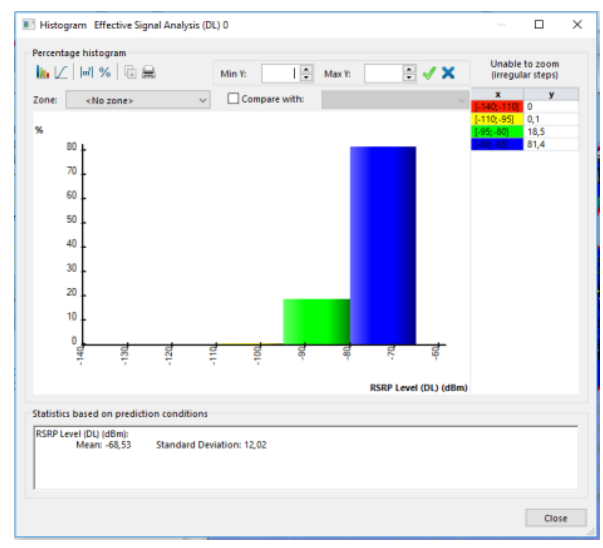

Gambar 8 Historam RSRP Skema Standalone

Gambar 8 merupakan hasil dari simulasi coverage RSRP pada skema Standalone. Pada gambar hasil simulasi RSRP pada Standalone menunjukkan $80 \%$ dari simulasi RSRP bernilai sebesar $-80 \mathrm{dBm}$. Sedangkan, merupakan histogram yang diperoleh dari hasil simulasi performansi coverage dengan parameter yang dianalisa ialah RSRP pada Standalone yang memiliki nilai rata - rata $-68,53 \mathrm{dBm}$.

Tabel 8 Hasil Parameter RSRP

\begin{tabular}{|c|c|}
\hline Skema Model & RSRP $(\mathrm{dBm})$ \\
\hline Standalone & $-68,53$ \\
\hline
\end{tabular}

Berdasarkan analisa performansi coverage yang dilakukan pada skema Standalone dengan parameter yang dianalisa adalah nilai dari RSRP. Dari nilai rata - rata RSRP yang diperoleh pada Standalone memiliki nilai yang termasuk dalam kategori sangat baik yaitu $-68,53 \mathrm{dBm}$ dari hasil simulasi.

Nilai rata- rata yang diperoleh dari hasil simulasi coverage terhadap RSRP pada skema Standalone memiliki nilai sebesar $-68,53 \mathrm{dBm}$ Hal ini dikarenakan penggunaan nilai power pada skema Standalone. Berdasarkan dari hasil simulai coverage terhadap RSRP penggunaan power mempengaruhi nilai RSRP yang diperoleh pada skema standalone.

\section{Analisis Performansi Coverage Skema Standalone Terhadap SINR}

Analisa performansi coverage pada skema Standalone terhadap parameter yang dianalisis adalah nilai SINR pada kedua skema. SINR merupakan perbandingan kuat sinyal terhadap noise interferensi. Sehingga, nilai SINR mempengaruhi kualitas pelayanan terhadap device user. Nilai dari SINR berdasarkan referensi yang diperoleh untuk NB-IoT ialah apabila nilai SINR lebih besar dari -1 dB maka SINR termasuk ke dalam kategori bagus. Akan tetapi, jika nilai SINR lebih kecil dari $-1 \mathrm{~dB}$ maka nilai SINR termasuk ke dalam kategori buruk. 


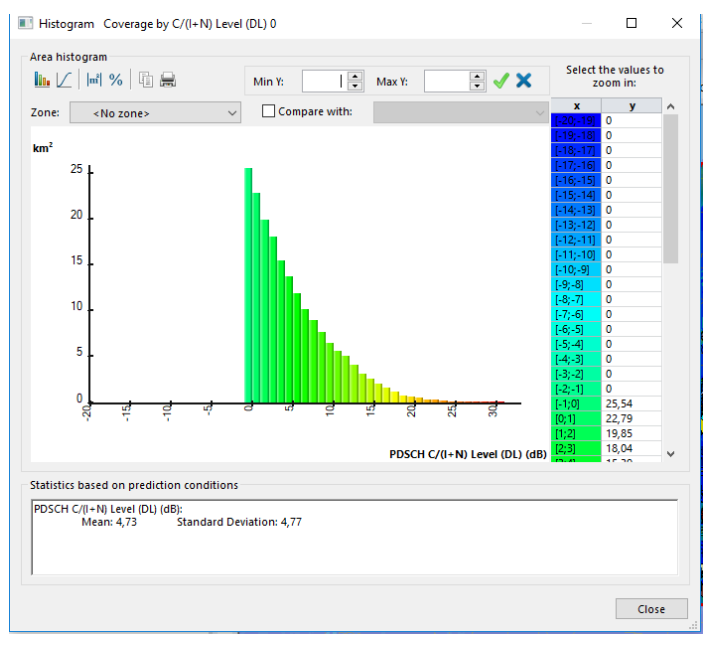

Gambar 9 Histogram SINR Skema Standalone

Gambar 9 merupakan histogram simulasi parameter performansi coverage SINR yang dilakukan pada skema Standalone. Pada gambar histogram dari simulasi tersebut, menampilkan nilai SINR dengan nilai rata - rata yang diperoleh SINR pada skema Standalone adalah 4,73 dB.

Tabel 9 Hasil Parameter SINR

\begin{tabular}{|c|c|}
\hline Skema Model & SINR $($ dB $)$ \\
\hline Standalone & 4,73 \\
\hline
\end{tabular}

Simulasi performansi coverage terhadap SINR memeproleh nilai rata - rata SINR untuk skema Standalone mengasilkan nilai sebesar 4,73 dB. Nilai SINR yang diperoleh pada skema Standalone termasuk ke dalam kategori bagus. Nilai SINR yang diperoleh dapat pula dipengaruhi oleh nilai penggunaan power pada skema, dan berdasarkan dari ferensi yang diperoleh nilai RSRP juga mempengaruhi nilai SINR. Yaitu, semakin besar nilai RSRP maka nilai SINR akan semakin bagus, yang dapat dilihat nilai RSRP pada Standalone sebesar - 68,53 dBm dengan nilai SINR sebesar 4,73 dB.

\section{Analisis Performansi Coverage Skema Standalone Terhadap BLER}

Analisis performansi coverage pada skema skema Standalone terhadap parameter yang dianalisa adalah nilai dari BLER pada kedua skema. Pada simulasi coverage nilai BLER merupakan rasio perbandingan antara nilai total block eror terhadap total blok terhadap transmisi dari sebuah data informasi yang dikirimkan pada skema Standalone. Nilai BLER sendiri dikatakan bagus apabila memiliki nilai tidak lebih dari $10 \%$ semakin besar nilai BLER maka nilai akan mengakibatkan banyaknya data informasi yang eror saat transmisi.

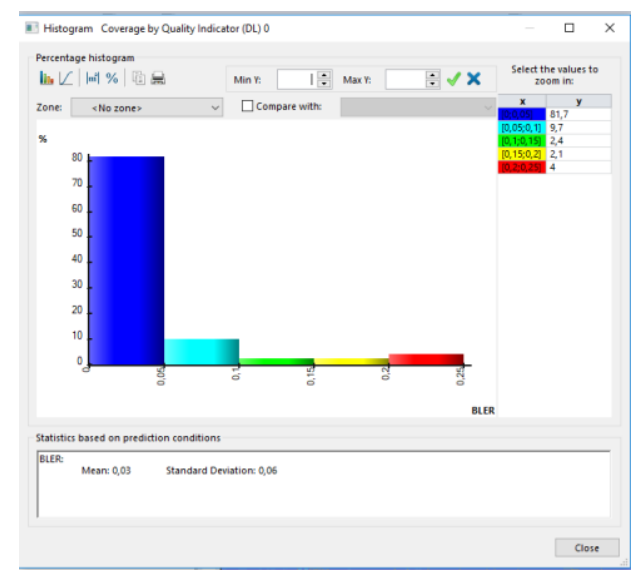

Gambar 10 Histogram BLER Skema Standalone 
Gambar 10 adalah histogram dari nilai BLER pada skema Standalone. Dari hasil simulasi pada skema Standalone memperoleh nilai rata - rata BLER sebesar 0,03 untuk skema Standalone.

Tabel 10 Hasil Parameter BLER

\begin{tabular}{|c|c|}
\hline Skema Model & BLER \\
\hline Standalone & 0,03 \\
\hline
\end{tabular}

Berdasarkan hasil dari simulasi coverage terhadap BLER pada skema Standalone memperoleh, nilai rata - rata yang sama untuk nilai BLER yaitu sebesar 0,03. Berdasarkan referensi yang diperoleh nilai BLER tidak mengalami perubahan yang signifikan pada simulasi NB-IoT.

\section{KESIMPULAN}

Kesimpulan yang diperoleh dari hasil penelitian Analisa performansi LTE NB-IoT meggunakan Standalone frekuensi $900 \mathrm{MHz}$ di DKI Jakarta ialah, hasil perhitungan untuk memperoleh jumlah subscriber pada area DKI Jakarta berdarsarkan jumlah penduduk dan luas area jumlah subscriber sebesar 31.758. Untuk hasil dari simulasi performansi kapasitas pada skema Standalone terhadap user connected dengan input subscriber sebesar 31.758 menghasilkan jumlah device user yang terhubung sebesar 109.933 device user. Sedangkan, hasil simulasi performansi terhadap throughput memperoleh nilai sebesar 85 Mbps. Hasil simulasi coverage untuk nilai RSRP pada skema Standalone sebesar -68,53 dBm. Hasil simulasi performansi coverage pada skema Standalone nilai SINR yang dihasilkan sebesar 4,73 dB. Berdasarkan simulasi performansi parameter Nilai power yang dimiliki skema standalone tidak mempengaruhi nilai SINR dan RSRP pada skema Standalone.

\section{ACKNOWLEDGMENT}

Penulis ingin mengucapkan kepada semua pihak yang membantu penelitian penulis, baik itu dosen pembimbing, tutor serta dosen yang sudah mendukung penelitian penulis.

\section{REFERENCE}

[1] Telkomsel, 201, “Telkomsel dan UI Implementasi Inovasi NB-IOT Bike Sharing" diakses pada tanggal 08 Desember 2018 dari https://www.telkomsel.com/about-us/news/telkomsel-dan-ui-implementasikan-inovasi-NB-IOT-bike-sharing.

[2] Mangalvedhe N, Ratasuk R, Ghosh A. "NB-IOT Deployment Study For Low Power Wide Area Cellular IOT”, IEEE, International Symposium on Personal, Indoor, and Mobile Radio Communications. IEEE, 2016: 1-6

[3] ITU Network Planning,"Developing The ICT Ecosystem to Harness IoT”, Bangkok, 2016.

[4] Wang Y P E, Lin X, Adhikary A, et al. A Primer on 3GPP Narrowband Internet of Things (NB-IoT) [J]. IEEE Communications Magazine, 2016, 55(3).

[5] Min Chen, Yiming Miao, Yixue Hao, and Kai Hwang, "Narrwoband Internet of Things",IEEE Access, September 2017.

[6] Kusumawati Diah, Setiawan Denny, Suryanegara Muhammad, "Spectrum Requirement For IoT Service A Case of Jakarta Smart City", IEEE International Conference on Communicatiopn, Network and Satelite, 2017.

[7] Hikmaturokhman Alfin, Komunikasi Seluler Multiple Access, Sekolah Tinggi Telkom Purwokerto, Purwokerto, 2016.

[8] F. A. FANANI, Analisa Perencanaan Jaringan Lte (Long Term Evolution) Fdd Frekuensi 900 Mhz Dan 1800 Mhz Di Area Yogyakarta. Purwokerto, 2016

Rapeepat Ratasuk, Jun Tan, Nitin Mangalvedhe, Man Huang Ng, and Amitava Ghosh, “ Analysis of NB-IoT Deployment in LTE Guard-Band", Mobile Radio Researc Lab, Nokia Bell Labs, 2017.

[9] Mobile IoT, NB-IoT Guide Deployment to Basic Feature Requirements, Diakses Pada Tanggal 22 September 2018, www.gsma.com/IoT

[10] Rapeepar Ratasuk, Benny Vejlgaard, Nitin Mangalvedhe, and Amivata Ghosh," NB-IoT System for M2M Communication", Mobile Radio Research Lab, Nokia, 2016.

[11] Ansuman Adhikary, Xingqing Lin, and Y.P Eric Wang, "Performance Evolution of NB-IoT Coverage", Ericson Research, 2017.

[12] A. Hikmaturokhman et al., 4G Handbook Edisi Bahasa Indonesia, Jilid 1., no. April. Jakarta: www.nulisbuku.com, 2014. 